Matusz Márk Péter ${ }^{1}$

\title{
A csapategészségügyi ellátást támogató egészségügyi applikációban rejlő lehetőségek
}

\section{Possibilities of Cellphone Applications in the Field of Military Healthcare System}

\begin{abstract}
Absztrakt
A cikkben röviden bemutatom az infokommunikációs forradalom telefonos applikációkat érintö egyes vívmányait és néhány egészségügyi ellátást támogató alkalmazást. Ezekből meghatározom, hogy milyen funkciócsoportok használatával lehetne képes a Magyar Honvédség csapategészségügyi szolgálata az állomány ellátásán javítani, valamint annak minöségét fokozni. Megvizsgálom ezenkívül a bevezetésre javasolt egészségügyi applikáció egyes kiberbiztonsági rizikófaktorait és ennek kiküszöbölésére megoldásokat javaslok.
\end{abstract}

Kulcsszavak: infokommunkiációs forradalom, telefonos applikáció, telemedicina, kibervédelem

\section{Abstract}

The article aims to introduce the achievements of infocommunication revolution regarding cellphone applications. Based on this all the functional groups will be defined that would enable the Hungarian Defence Forces to improve the military healthcare system, and to upgrade its quality. Besides, the cyber security risk factors of the suggested healthcare application will be examined and solutions will be suggested in order to eliminate these factors.

Keywords: infocommunication revolution, cellphone application, telemedicine, cyber defence

Doktorandusz, Nemzeti Közszolgálati Egyetem, Katonai Müszaki Doktori Iskola - University of Public Service, Doctoral School of Military Engineering, PhD student, e-mail: matusz.mark@mil.hu, ORCID: https://orcid.org/0000-0002-3768-1079 


\section{Bevezetés}

A harmadik évezredben az infokommunikációs forradalom és fejlődés (látszólag) feltartóztathatatlanul zajlik. Egyre több ember rendelkezik okostelefonnal és interneteléréssel, ennek következtében a világon az információáramlás döbbenetes mértékben felgyorsult. A folyamatban rejtőző potenciál kihasználására számos út létezik - nap mint nap olvashatók beszámolók kreatív és hasznos megoldásokról, amelyekben mind ott rejtőzik a lehetőség, hogy napjaink részeivé váljanak. (Mielőtt belekezdek ezeknek az alternatív utaknak a bemutatásába, kezdjük a legelején, hogy a fejlődés jellegét és kiterjedését a lehető legpontosabban felmérhessük.) Stefan Detschew könyvéböl Lengyelné dr. Molnár Tünde és dr. Kiss-Tóth Lajos fordításában az információs és kommunikációs technikák összesítik „a teljes körü technológiai tervezést az információhoz való hozzáféréstől a feldolgozáson át az átadásig: az információ gyüjtésének, tárolásának, továbbításának és prezentálásának hardver-, szoftver- és média feltételeit, legyen az információ formája hang, adat, szöveg vagy kép. Magában foglalja a telefon, mobiltelefon, hardver, szoftver területét egészen az internetig."'

A folyamat volumenét kiválóan demonstrálja a magyarországi internet-elöfizetések számának emelkedése: míg 2010-ben 3,3 millió volt, addig 2016-ig 5,7 millióval, azaz évente átlagosan 18\%-kal bővült. Ami ebből a markáns számadatból értekezésem témájához illeszkedik, az a magyarországi mobilinternet-előfizetések számának emelkedése: 2016-ban az internet-előfizetések száma 8,1\%-kal emelkedett az előző évihez képest. A mobilinternet adja az összes internet-előfizetés több mint kétharmadát (69\%). ${ }^{3}$ Világviszonylatban a fent említett számok még markánsabban megmutatkoznak, két adattal szeretném ezt szemléltetni: 2018 januárjában már 3,7 milliárd internethasználóval számol a statisztika, valamint 2019-re a világ népességének mobiltelefon-használói közül 63,4\% készülékén is rendelkezik interneteléréssel. ${ }^{4}$

Az adatátvitel sebessége, az applikációk kínálata, és ezzel együtt az elvégezhető műveletek, lehetőségek sora folyamatosan bővül. Az okostelefonok folyamatos térnyerésével ezek az eszközök immár a felhasználók egyfajta személyi asszisztenseivé léptek elő. Bonyolíthatjuk a levelezéseinket, közös naptárban harmonizálni tudjuk tervezett elfoglaltságainkat a hozzánk közel állókkal, különböző közösségi hálózatokon akár a nap 24 órájában kapcsolatot tudunk tartani távoli ismerőseinkkel. Applikáción keresztül elérhetőek a legfrissebb hírek, elindítható navigáció, ha eltévedtünk, megrendelhetők a legkülönfélébb vágyott termékek, nyomon követhetők a különböző menetrendek és változásaik, rá lehet pillantani az esti TV-müsorra vagy lefoglalható és kifizethető mozijegy is. Az applikációk komolyabb és felelősségteljesebb feladatok elvégzésére is alkalmasak: a pénzügyek intézésére már a legtöbb bank saját mobilalkalmazással rendelkezik, továbbá megjelentek az egészséget monitorozó applikációk is. A folyamatok felgyorsulásával, az átlag felhasználókban kialakult az „itt és most igénye”, azaz

Stefan Detschew: Impact of ICT in the developing countries on the economic growth. Norderstedt, GRIN, 2007. 28. Definíció fordítása: http://okt.ektf.hu/data/szlahorek/file/kezek/05_ikt_02_27/index.html (A letöltés dátuma: 2019. 04. 21.) Az infokommunikációs technológiák és szolgáltatások helyzete Magyarországon, 2016. Központi Statisztikai Hivatal, 2016. 4. Elérhetö: www.ksh.hu/docs/hun/xftp/idoszaki/ikt/ikt16.pdf (A letöltés dátuma: 2019. 04. 25.)

Mobil Internet Statistics and Facts 2019. Internet Stats and Facts for 2019. Elérhető: https://hostingfacts.com/internet-facts-stats/ (A letöltés dátuma: 2019. 04. 25.) 
a felmerülő információigényének az azonnali teljesítési lehetőségét keresi. Az emberek hozzászoktak, igénylik és használják az okostelefonon kialakított információszolgáltatásokat. A napi életük zökkenőmentes végzéséhez, illetve kényelmi szempontok alapján is, az emberek ragaszkodnak a használt szolgáltatásokhoz. Kijelenthetjük, hogy az emberek életének és egyben komfortérzetének meghatározó részévé vált az infokommunikáció és az ezt megtestesítő okostelefon. Ezt a jelenséget próbálják meg minél jobban kiszolgálni a mobilkommunikációs gyártók és a szoftverfejlesztő cégek.

A civil szférában megfigyelhető egyes infokommunikációs jelenségek megnevezése után szűkítsük a kört a Magyar Honvédségre, azon belül is a csapategészségügyi ellátás rendszerére. Tekintsük át, hogy a csapategészségügyi szolgálat milyen infokommunikációs képességekkel rendelkezik és megfigyelhető-e bármiféle párhuzam a két terület között. A Magyar Honvédség csapategészségügyi szolgálatának jelenlegi infokommunikációs fejlettségét két területre osztom. Mobil és a helyhez kötött képességek alapján fogom csoportosítani a rendelkezésre álló lehetőségeket.

Mobil infokommunikációs képességként az egészségügy területén igénybe vett opciók közül kizárólag a meghatározott beosztásokhoz igényelhető szolgálati telefon, valamint az ehhez járó meghatározott adatmennyiségű mobilnet, illetve a feladatspecifikusan felvehető EDR rádió említhető meg.

Helyhez kötött infokommunikációs lehetőségként bemutatható:

- USB stickkel igényelhető internetes elérhetőséget biztosító SIM-kártya,

- HM Internet, amelyet a MedWorkS egészségügyi informatikai rendszer és az ORKA Orvosi Recept Kitöltő Alkalmazás használ,

- HM Intranet, amely belső hálózatként müködik, és magában foglalja az elektronikus levelezés opcióját,

- HM távbeszélő hálózat, azaz irodai vezetékes, belső telefonhálózat,

- irodai telefaxkészülék.

Ahogy a felsorolásból is látszik, a rendelkezésre álló infokommunikációs lehetőségek biztosítják mind az együttműködésre, mind az információátadásra a lehetőséget. Tehát a müködés, az egészségügyi ellátás működtetése minimumfeltételeinek a rendszer eleget tesz, bár nem a 21. század infokommunikációs lehetőségeihez mérten.

Felmerül a kérdés, hogy a civil szférában már müködő innovációkat és előremutató fejlesztéseket hogyan lehetne a Magyar Honvédség csapategészségügyi ellátás szolgálatába állítani? Melyek azok a lehetőségek, amelyekkel az állomány egészségügyi ellátásának sebességét, a prevenció, a diagnosztika, terápia és gondozás területén fokozni tudnák a minőség romlása nélkül? További kérdésként merül fel, hogy a jelenlegi honvédségi egészségügyi ellátó rendszer mennyire alkalmas a potenciálisan bevezethető innovációk kezelésére, integrálására?

Célul tűztem ki, hogy egy egészségügyi applikáció elméleti bemutatásával demonstráljam a további hasznosítási lehetőségeket és az alkalmazásban rejlő potenciált. Kutatásom során elsősorban az analízis módszerével elemeztem a vonatkozó elektronikus és a nyomtatott hazai és külföldi szak- és tudományos irodalmakat. Másodsorban lehetőségem adódott az egészségügy területén dolgozó szakemberekkel strukturálatlan interjúk készítésére, amelyeknek tapasztalatait az értekezésembe beépítettem. 


\section{Fontosabb egészségügyi applikációk hazánkban és a (nagy)világban}

Annak érdekében, hogy átfogó képet tudjak mutatni a jelenlegi infokommunikációs trendekről és azon belül az okostelefonokra írt egészségügyi applikációkról, ebben a fejezetben bemutatok néhány népszerü hazai és külföldi fejlesztést, amelyek olyan innovatív tartalommal rendelkeznek, amelyeket a csapategészségügyi ellátás fejlesztésében is sikerrel lehetne alkalmazni. Mivel az applikációkat nagy többségben vagy Android, vagy IOS operációs rendszerre írva fejlesztették ki, abból a feltételezésből indulok ki, hogy a szoftverfejlesztők a potenciális igénybe vevők vagy vásárlók, illetve a szoftverpiac igényének lehető legteljesebb elérése érdekében mind a két platformra kifejlesztik applikációjukat, így elégséges az egyik letöltése és tesztelése.

Első bemutatandó alkalmazásnak a „Doctor On Demand”-ot választottam. ${ }^{5}$ Az alkalmazás legfontosabb jellemzője, hogy lehetőséget biztosít a felhasználó számára, hogy az okostelefon kameráját felhasználva, élő, online kapcsolatba tudjon lépni egy orvossal vagy pszichológussal, akinek az egészségügyi vagy lelki eredetü problémájáról beszélhet. Az alkalmazás menürendszerében mutatja a rendelkezésre álló egészségügyi szakembereket, valamint jelzi a várakozási időt is. A program beépített naptár funkcióval is rendelkezik, ami alapján lehetőség van időpontot előre foglalni. A szakemberrel történő konzultáció minőségének javítása érdekében, az applikáció rendelkezik beépített kérdőívvel a páciens aktuális tünetei tekintetében. Figyelmesség a fejlesztők részéről, hogy az okostelefon GPS-koordinátái alapján meg tudja mutatni a legközelebbi gyógyszertárat is.

A következő bemutatandó példa koncepciója illeszkedik kutatásomba, viszont kizárólag a weben érhető el, önálló applikáció nem készült belöle. Az Egyesült Államok hadseregének „Army Knowledge Online"6 portálját mutatom be az alábbi indokok alapján. A honlaphoz az amerikai hadsereg minden aktív és nyugállományú katonája automatikusan hozzáférést kap. Azzal a céllal hozták létre a portált, hogy biztonságos környezetben biztosítson hozzáférést és lehetőséget adatok és információk megosztásához, valamint a fent említett csoportok kommunikációs lehetőséghez jussanak, beépített chat és e-mail-funkció formájában. A tagoknak lehetőségük van egyes katonai feladataik jelentéseihez hozzáférni, saját pénzügyi, financiális helyzetüket megtekinteni, valamint különböző e-oktatás(ok)on részt venni. A felsoroltakon kívül a tagok saját egészségügyi dokumentációjukat is nyomon tudják követni. $A$ „The Wounded Warrior", azaz a sebesült harcos részegysége pedig a megfelelő diagnózis felállításában és az azt követő rehabilitációban próbál segíteni. A portál lehetőséget biztosít úgynevezett másodhozzáférések megigénylésére a hadsereghez köthető vállalkozók, önkéntesek és a katonák családtagjai részére.

Doctor on Demand alkalmazás. Elérhetö: https://itunes.apple.com/us/app/doctor-on-demand/id591981144?mt=8 (A letöltés dátuma: 2019. 04. 25.)

6 What is Army Knowledge Online? Elérhető: www.onlinemilitaryeducation.org/faq/what-is-army-knowledge-online/ (A letöltés dátuma: 2019. 04. 25.) 
A harmadik választott alkalmazás Withings Health Mate ${ }^{7}$ nevű applikáció. A programot a személy egészségi állapotának javítása, fejlesztése céljából, valamint az úgynevezett egészséges életmód kialakítása, továbbá annak megőrzése céljából fejlesztették ki. Ezeknek a céloknak az elérésére egy átlátható menürendszert alkottak meg a fejlesztők. A menürendszerben megjelennek a programot használó személy egészségügyi adatai, mozgás-, aktivitásmennyiségei, alvási naplója, súlya vagy mért egészségügyi értékei, például a vérnyomása. Az aktivitás menüpontban a program a telefon beépített GPS-adatai alapján naplózza a megtett távolságokat és segít motiválni a mozgás rendszeres fenntartásában különböző tréningek (egyszerű edzéskihívások, például 10 ezer lépéses edzés), rendszeres testsúlymérés és a táplálkozás nyomon követése formájában.

A negyedik applikációt az oktatás területéről választottam ki, ez a Medscape CME \& Education. ${ }^{8}$ A program teljes valójában regisztráció után elérhető, ahol az érdeklődőnek a végzettségét is meg kell adnia. Az applikáció főoldala az egészségügy területén megjelenő hírekre, eseményekre épít, és a regisztrált felhasználó végzettségének megfelelő cikkeket, témákat hoz fel bemutatásra. A gyógyszerek és betegségek menüpontokban lehetőség nyílik többek között egyes egészségügyi ellátások eljárási módszereinek, protokolljainak megismerésére, anatómiai demonstrációk megtekintésére, gyógyszer-azonosító program használatára, laborértékek magyarázataira. A beépített medikalkulátorok segítenek az egészségügyi szakembernek egyes helyzetekben a gyors számolásra és az esemény bekategorizálására. A gyógyszer kölcsönhatás alpont hasznos kiegészítés, segít egyes kérdésekben a megfelelő gyógyszer kiválasztásában. Az oktatás menüpontban a fontosabb cikkek elmentésén kívül lehetőség adódik érdeklődési területünknek megfelelően navigálni és keresni is. Az applikáció nagyon komoly súlyt fektet az oktatásra, nagy mennyiségü videóalapú oktatási anyag hozzáférhető, amely egyéni fejlődésre kiválóan felhasználható. Az applikáció különböző írott kurzusokon való részvételre is bátorít, ahol a továbblépéshez a fejezet végén tesztben kell számot adni a megszerzett tudásról.

A magyarországi applikációkínálatból ilyen részletekbe nyúló gazdagsággal és ilyen komoly információtartalommal feltöltött alkalmazásokat, mint az Egyesült Államokból bemutatott példák, nem találtam. Ennek ellenére látókör-szélesítés céljából szeretnék bemutatni ígéretes kezdeményezéseket. Egyetlen kissé elbizonytalanító tényezőre szeretnék előre rámutatni: a bemutatott magyarországi applikációk (IOS platform) - MediCall kivételével - 2-4 éve kaptak szoftverfrissítést utoljára. Ebből azt a következtetést vonom le, hogy a fejlesztők nem látnak bennük akkora potenciált, hogy az infokommunikációs fejlődés ad hoc jellegű kihívásaira lehetőség szerinti gyors válasszal reagáljanak, és naprakészen tartsák a programok információs bázisát, valamint a folyamatosan felmerülő biztonsági és módosítási, javítási szempontokat is figyelembe vegyék.

A „WebDoki"9 applikációt 3 éve frissítették utoljára. Nyitófelülete egy tájékoztatóval fogad: kizárólag orvosoknak szóló zárt portál, amely regisztrációt követően vehető igénybe. A feltöltött bemutatkozó anyagok alapján helyet biztosít több szakmai

Withings Health Mate. Elérhető: www.withings.com/nl/en/health-mate (A letöltés dátuma: 2019. 04. 25.)

Medscape. Elérhető: www.medscape.com (A letöltés dátuma: 2019. 04. 25.)

WebDoki. Elérhető: www.webdoki.hu/logon/?redirect=\%2F\#login (A letöltés dátuma: 2019. 04. 25.) 
fórumnak, nyomon követi és összefogva mutatja be a továbbképzési lehetőségeket. Ezenkívül az egészségügyet érintő hírekkel is szolgál. Rendelkezik BNO-keresővel, a laborértékekről tájékoztatást ad, valamint gyógyszeradatbázist és gyógyszerkölcsönhatás-vizsgálati lehetőséget is beépítettek.

A „Patikus"10 elnevezésű alkalmazás 2 éve frissült utoljára. Az alkalmazást a Budapesten gyógyszertárat keresők részére készítették, erről az információs funkcióba beletekintéskor a program külön tájékoztat is. A program GPS-használatra kér engedélyt, és az adatbázisa alapján a GPS-adatokhoz viszonyítva méter pontossággal megmondja a távolságot, akár 17 km távolságra is a legközelebbi patikától. Nem navigál oda, pusztán a címet írja ki. Mivel adatbázisa nem a legfrissebb, értelemszerủen a nyitvatartási idők és az újonnan nyílt egységek nem szerepelnek benne. Az ügyeleti funkció kipróbálásakor nem jelzett ki egyetlen választható alternatívát sem. $349 \mathrm{Ft}$ felárért a program hozzáférést ad 11603 BNO-kódhoz, amelyekben keresési lehetöséget biztosít akár a betegség neve alapján is.

A „Medical Point+"11 applikációt 4 éve frissítették utoljára. A program honlapján olvasható tájékoztató alapján az applikációt kifejezetten segítségnyújtás céljából alkották meg. Célja, hogy a felhasználóhoz legközelebbi gyógyszertárakat, orvosi és fogorvosi rendelőket, véradó- és oltóhelyeket megmutassa. Az alkalmazás tájékoztatója alapján beépített útvonaltervezője is van, valamint amennyiben az úticél rendelkezik telefonos elérhetőséggel, a program azt tárcsázni is tudja. Kreatív újítás a profil testreszabhatósága, amely akár egészségügyi adatokkal is feltölthető, akik ezen adatok alapján azonnali információhoz juthatnak a sérültről. Sajnos a program müködéséről nem sikerült gyakorlati tapasztalatot szereznem, ugyanis a teszteléshez használt IPhone $X$ telefonkészülék a cikk írásakor elérhető legfrissebb szoftververzióval (12.2) nem tudta az alkalmazást elindítani, az mindig kilépett.

A MediCall ${ }^{12}$ applikáció legutolsó frissítése 2 hónapja történt, tehát kijelenthető, hogy a bemutatott applikációgyűjteményből az egyetlen, amelyik friss támogatással rendelkezik. Gyors regisztrációt elvégezve, első belépés után a program még elkéri a telefonszámot, mielőtt a menüpontokhoz teljes hozzáférést kapunk. Három opció közül választhatunk: helyszíni vizit, telefonos konzultáció és mentő hívása. Az applikáció korrekten a szolgáltatások aktuális tarifáit is diszkréten jelzi. A helyszíni vizitnél első lépésként ki kell választani, hogy felnőtt vagy gyermek páciensröl van-e szó, utána a pontos címünk megadása következik, majd az orvos kiválasztása. A telefonos konzultáció menüpontban az orvosok listája alapján vagy szakterületenkénti szürésben is elindulhatunk. Az orvos fényképén egy diszkrét zöld vagy szürke pont mutatja az elérhetőséget. Az orvos fényképére kattintás után, elérhetőség esetén megjelenik a hívás menüpont. A program naplózza a szolgáltatás-igénybevételeket, segítve ezzel, hogy visszataláljunk a kiválasztott orvoshoz, illetve a félreértések elkerülése végett visszanézhessük az igénybe vett szolgáltatásokat.

10 Patikus. Elérhető: https://itunes.apple.com/hu/app/patikus/id579890723?l=hu\&mt=8 (A letöltés dátuma: 2019. 04. 25.)

11 Medical Point+. Elérhető: https://itunes.apple.com/hu/app/medical-point/id643000486?l=hu\&mt=8 és http:// easy-marketing.eu (A letöltés dátuma: 2019. 04. 25.)

12 MediCall. Elérhető: https://medicall.cc (A letöltés dátuma: 2019. 04. 25.) 
Ebben a fejezetben röviden áttekintettem az amerikai és a magyarországi egészségügyi applikációkínálatot. Arra a megállapításra jutottam, hogy az egészségügyi támogató, szervező applikációknak van létjogosultságuk. Az alkalmazások sokrétúsége bizonyítja, hogy ezen a területen a potenciális és valós felhasználók igényei és az applikációk feladatrendszere, képességei fedik egymást. Igény mutatkozik az egészséges életmód összetevőinek bemutatására, illetve az életmódváltás fenntartásához szükséges lépések folyamatos megerösítésére. Megerősítést nyert, hogy az emberek igénylik az egészségügyi szolgáltatások akár otthonukba történő kiterjesztését, valós igény rajzolódik ki a telefonos orvositanácsadás-szolgáltatásban. Ezt igazolták a programok letöltési helyén megtekinthető felhasználói visszajelzések és az értékelések mennyisége is.

\section{Tervezett egészségügyi applikáció}

Ahogy a röviden bemutatott piaci körképböl ismertettem a felhasználók igényeit, valamint demonstráltam a jelenlegi applikációkban rejlő lehetőségeket, meg kell fogalmazni, hogy a Magyar Honvédség csapategészségügyi rendszerét az alkalmazások mely funkciói erősítenék.

Ahhoz, hogy ez biztonsággal megfogalmazható legyen, szükségesnek tartom a Magyar Honvédség csapategészségügyi rendszerének jelenleg legnagyobb megoldandó problémájáról szót ejteni.

A 2012-es esztendőtől kezdve, Magyarországon egyre inkább elkerülhetetlen, hogy szembenézzünk a kialakult orvos-, szakorvoshiánnyal, ami alól a Magyar Honvédség sem kivétel. A Magyar Honvédség számára kedvezőtlen munkaerőpiaci folyamat(ok) a saját orvosi állományát is érinti, a jelenség a Magyar Honvédség orvosutánpótlásának csökkenésében markánsan tetten érhető. Az alakulatoknál ma már elvétve találkozunk katonaorvossal, helyüket a részmunkaidős közalkalmazotti jogviszonyban feladatot végrehajtó állománnyal próbálja kiegyensúlyozni a rendszer. A kialakult helyzet kezd kritikus méreteket ölteni: a betegellátáson kívül, az egyre növekvő feladatok a megmaradt szakembergárdára hárulnak. Az egy orvosra jutó feladatrendszert és napi betegellátási számot racionalizálni kell, különben az orvoslétszám további apadása nem lesz megállítható. Az orvosok leterheltségének csökkentése, illetve a jelenlegi helyzet megoldása érdekében célirányos, áthidaló, racionalizáló megoldások mielőbbi kifejlesztése és gyakorlati alkalmazása szükséges.

Ennek a folyamatnak a megoldása első lépéseként egy olyan egészségügyi applikáció bevezetését javaslom, ami képes lenne az egészségügyi ellátás folyamatának több pontján támogatást kifejteni, amely által részben tehermentesül a jelenlegi szakszemélyzet, valamint az egészségügyi ellátás minősége és spektruma jelentős mértékben kibővül.

Első lépésként bemutatom az applikáció felépitését, utána pontról pontra az alkalmazás menüjét. 


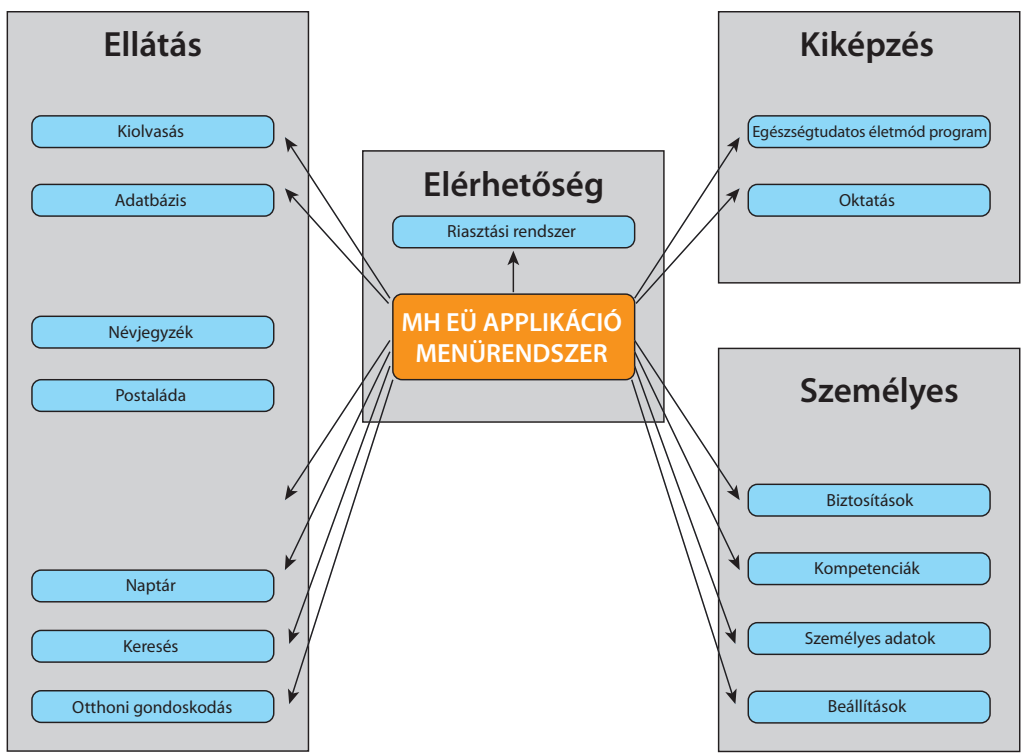

1. ábra: A Magyar Honvédség egészségügyi applikáció felépitése (egészségügyi szakemberek részére).

Forrás: a szerző szerkesztése

A menüpontok kibontása előtt fontosnak tartom megjegyezni, hogy az applikációt két verzióban terveztem meg. Az egyik verziót az egészségügyi szakállomány részére fejlesztettem ki (a fenti ábrán is ez szerepel), míg a másikat a nem egészségügyi beosztásban feladatot végrehajtó katona állománynak. A két verzió közti különbség, hogy a nem egészségügyi felhasználásra tervezettben a „Kiolvasás" és az „Adatbázis” menüpont nem szerepel.

Az Ellátás menü azokat a pontokat és funkciókat tartalmazza, amelyek a gyakorlati egészségügyi ellátással vannak kapcsolatban.

- Kiolvasás: a kiolvasás tulajdonképpen egy szkennelő funkció, amely az okostelefon kameráját használja. Célja, hogy egy vészhelyzetnél a katona megreformált személyi igazolójegyén szereplő QR-kódból (elméleti koncepcióm) az ellátást segítő vagy azt esetlegesen veszélyeztető egészségügyi információkkal az ellátást segítse. ${ }^{13}$

- Adatbázis: speciális vagy minősített eset(ek)ben, szigorúan temporálisan kiadott engedélyek alapján a Magyar Honvédség katona állományának egészségügyi adataihoz nyújthat kompetenciaalapú hozzáférést egyes egészségügyi beosztást betöltők részére. Alaphelyzetben az egészségügyi beosztást betöltő kizárólag a közvetlenül ellátandó saját állományának egészségügyi adataihoz fér hozzá. Ezenkívül a menüpont tárolja a magyarországi háziorvosi rendelők, gyógyszertárak, laboratóriumok, rendelőintézetek, oltóközpontok, kórházak,

3 Matusz Márk: A személyi igazolójegy („dögcédula”) fejlesztési lehetőségei a telemedicina vonatkozásában. Hadmérnök, 13. (2018), 4. 370-380. 
sürgősségi osztályok folyamatosan naprakészen tartott GPS-koordinátáit, pontos címeit, telefonos elérhetőségeiket.

- Névjegyzék: a vezetési rend alapján, a hierarchikus szintek kijelölt kapcsolattartóinak elérhetőségét biztosítja a menüpont. Markáns előnye, hogy a központi frissíthetőség és módosítás következtében bármely elérhetőségben történő változás azonnal eljut akár a végrehajtói szinthez is, hiszen a mobiltelefon mindig a személynél található. Ennek kézzelfogható előnye ott fog megmutatkozni, amikor a hagyományos információáramlási csatornákon eljuttatott információ késedelemmel érkezne meg a feladatba bevont állományhoz, ami esetlegesen - a kapcsolattartás nehézsége miatt - akár a feladat elvégzését is nehezítené, veszélyeztetné.

- Postaláda: amennyiben a mobilhálózat lefedettsége engedi, a belső levelezéshez biztonságos formában hozzáférést biztosít ez a funkció, természetesen mind fogadási, mind küldési lehetőséggel.

- Naptár: a funkció az alapellátás, illetve a foglalkozás-egészségügyi alkalmasság vizsgálatok ütemezésén és tervezhetőségén kíván javítani. A naptárfunkció képes nyomon követni az alkalmasságvizsgálatok lejáratának dátumát és ezt a személynek jelzi, lehetőséget adva, hogy a naptárban előjegyzést tegyen a szükséges vizsgálatokra, amelyet az egészségügyi szakállomány lát, és amennyiben nincs ütközés, azt jóváhagyással visszajelzi. Az egészségügyi alkalmazás naptár funkciójába igény esetén akár gyógyszerszedési emlékeztető is beépíthető, előnye a diszkréció, a bejegyzés a személy saját naptárában nem jelenik meg.

- Keresés: a funkció az okostelefon beépített GPS-ét és az internetet, valamint az adatbázis menüpont címlistáját használva, strukturáltan összegyüjti és mutatja (akár útvonaltervezővel) a felhasználóhoz legközelebb eső háziorvosi rendelőket, gyógyszertárakat, laborokat, rendelőintézeteket, oltóközpontokat, kórházakat, sürgősségi osztályokat.

- Otthoni gondoskodás: lényege, hogy a kapcsolat az egészségügyi ellátás és a katona között a munkaidő leteltével se szűnjön meg. Ezzel a lehetőséggel biztosítható egy „vékony köldökzsinórszerü” gondoskodási szál az állománynak munkaidőn túlra. A képesség azoknak szolgálhatna segítségül, akik kellő önkontrollal és józan problémabelátással rendelkeznek az egészségügyi problémájuk súlyát tekintve, a sürgősségi ellátást nem akarják terhelni, de egészségügyi szakembertől tanácsra (például akut tüneteknél, vagy gyógyszerszedéssel kapcsolatban), e-receptre, esetleg kontrollra (például telemedicinális EKG, vérnyomás, vércukormérés) igényt tartanának. A kiinduló gondolatom „telefonos" chat, amely munkaidőn túli, a hivatalos ügyeleti rendszer részeként tudna funkcionálni egy zárt kör, az adott alakulat személyi állománya részére. Első körben a chatalkalmazásban kizárólag az ügyeletet adó szakasszisztens szólítható meg, a szakasszisztens döntésének függvénye, hogy a probléma megoldásának folyamata orvos végzettségü személyig eljut-e.

Az Elérhetöség menüpont egy olyan funkció, amely az adott szakterületen (egészségügy) feladatot végrehajtókat füzi fel egy egységes kiértesítési rendszerre. 
A Riasztási rendszer három almenüpontra tagozódik. KFR, HKR és elrendelt készenléti szolgálat esetén biztosíthatja a személy zökkenőmentes elérését és a vele való információáramlást.

A Kiképzés menüpontja a személy szakterületén lévő naprakészségét, fejlődési igényét hivatott kiszolgálni, beépített online kurzus elvégzési lehetőséggel, továbbá lehetőséget ad az egészségtudatos életmód megismerésére és elsajátítására.

Egészségtudatos Életmód Program: Az egészséges életmód program célja, hogy az adott alakulat állományának lehetősége legyen szakemberek által irányítottan, az egészséges életmód összetevőivel és gyakorlati lépéseivel megismerkedni, valamint szándék esetén a programban részvétellel fejlődni. Ennek következtében értelemszerüen két részre válik, lesz aki résztvevőként fogja a meghatározott lépéseket teljesíteni, és lesznek, akik autodidakta módon érdeklődőként próbálják ki, és siker esetén teszik a napi életük részévé. Az applikáció segítséget nyújt a programban részt vevő szakembereknek, hogy a résztvevők egészségügyi értékeinek változását, illetve edzés-, sportolási mennyiségeit nyomon kövessék. Napjaink okostelefonjai lehetőséget biztosítanak, hogy a személy aktivitása és napi tevékenysége automatikusan vagy manuálisan naplózásra kerüljön. Az okostelefonok képességei, szenzorai akár a program és ezzel együtt a személy pontosabban vezetett dokumentációjára is felhasználhatók. Innen egy lépés az adatok megosztása egy előre kialakított felületen, tárhelyen, amelyről kompetencia alapján a szakszemélyzet részére hozzáférés biztosítható. Gyakorlati megvalósulását úgy képzelem el, hogy az alakulat egészségügyi központjának orvosa és pszichológusa, valamint az alakulat személyi edzője a programba jelentkezőknek orvosi vizsgálattal és az egészségügyi állapot folyamatos monitorozásával, viselkedésterápiával, táplálkozási tanácsadással és személyi edzéssel támogatja az életmódváltást. A telefonos applikáció az alábbi menüpontokból áll:

- Ütemezett egészségügyi vizsgálatok időpontjai;

- Egészségügyi mérések napló (vérnyomás, pulzus, vércukor, EKG, testsúly, BMI, zsír/izom aránya stb.);

- Mozgási napló (lépésszámláló, cardioedzések adatai);

- Táplálkozási napló (elfogyasztott étel és a napi bevitt kalóriamennyiség);

- Pszichológiai támogatás (személyiségfejlesztés, tesztek, relaxációk);

- Oktató- és ismertetőanyagok, tudnivalók:

- Elméleti háttér (tananyagok),

- Kalóriatáblázat,

- Mintaétrendek,

- Edzésminták,

- Felvilágosító információk - például káros szenvedélyekről.

Az Oktatás menüpont a személy szakterületének megfelelő oktatási anyagokkal, online kurzusok elvégzésének lehetőségével, a szakterületét érintő hírekkel, eseményekkel, információkkal fog szolgálni. Célja, hogy a személyben fenntartsa az érdeklődést a szakterülete irányába, biztosítsa az egyéni fejlődési igényeket, valamint igény esetén egyfajta „köldökzsinórként” szolgáljon, szimbolizálva a valahová tartozás igényét. Az alábbi menüpontokból áll: 
- Hírek, információk;

- Támogató, szakmai anyagok (például protokollok);

- Továbbképzés, elvégezhető kurzusok (Írásbeli, teszt alapú vizsgával. A kurzus súlyához mérten az applikációból elvégezhetően, vagy központilag, személyes megjelenéssel.);

- Képi, videóalapú oktatási anyagok.

Személyes menüpont tartalmazza azokat a funkciókat, amelyekkel az applikáció működése és annak teljes spektrumában történő kihasználása beállítható.

- Biztosítások (a személy feltöltheti milyen életbiztosítása van, mely egészségpénztárnak a tagja);

- Kompetenciák (egészségügyi beosztás betöltése esetén, az adott végzettség meghatározza a személy kompetenciaszintjét, azaz milyen mélységben, mekkora mennyiségben láthat rá és kezelhet egészségügyi adatokat - ld. Adatbázis menüpont);

- Személyes adatok (beállítható a személy elérhetősége, azonosításához szükséges adatainak és jelszavainak tárolóhelye);

- Beállítások (az applikáció értesítések megjelenítésének, grafikai stílusbeli, illetve hangalapú testreszabhatóságának pontja).

Az applikáció használatának fontosabb technikai, müszaki követelményeiről összefoglalóan elmondhatjuk, hogy bármilyen kétévesnél nem régebbi, középkategóriájú okostelefonra már telepíthetőnek tervezem. A körülbelüli kétéves korhatár azt hivatott meghatározni, hogy a telefon RAM-ja minimálisan 2 GB legyen, akkortól a gyártók már jellemzően elérték azt a kapacitást, ami már kényelmesen biztosítani tudja a stabil működést a felhasználó részére. Legyen csatolt Word alapú fájlok megnyitásáról szó, vagy HD-minőségű oktatóvideó lejátszásáról. Nem elvárt, de ajánlott a két SIM-kártya befogadására és müködtetésére alkalmas készülék, így a felhasználó szolgálati telefon átvétele esetén zökkenőmentesen illeszkedik a rendszerbe.

Biztonság, adatvédelem terén a kellő körültekintés mindenféleképpen indokolt, föleg abban az esetben, amikor érzékeny adatok kezelését tervezzük meg. A célom a komplex információbiztonság megteremtése. Haig professzor úr megfogalmazásában a komplex információbiztonság legfontosabb eleme annak céljában keresendő, az információs társadalom információbiztonsága szempontjából tehát a fő cél a kritikus információk megóvása. ${ }^{14}$

Mielőtt ennek a kiinduló kritériumrendszerét meghatározzuk, szükségesnek tartom ennek a területnek az alapvető fogalmait azonosítani. Egy rövid áttekintéssel kezdem.

A 21. században nyilvánvalóvá vált, hogy az informatika és a kommunikációs eszközök forradalmi fejlődésével mind az emberek, mind a különböző rendszerek (beleértve a hadseregeket is) függővé, kiszolgáltatottakká váltak korunk eme vívmányaitól. Ez alatt azt értem, hogy a különböző rendszeresített képességek müködését, működtetését nagymértékben befolyásolják az azt kiszolgáló számítógépes és kommunikációs hálózatok. Innen már csak egy lépés választ el egy ellenérdekelt országot,

14 Haig Zsolt: Az információs társadalom információbiztonsága. Bolyai Szemle, 17. (2008), 4. 167-180., $172-176$. 
hogy az informatika biztosította anonimitást kihasználva, inkognitóját megőrizve, ezeket a rendszereket támadva érjen el előnyt.

Felvetődik a kérdés, ahhoz, hogy meg tudjuk védeni a fent említett infokommunikációs támogató rendszert, először is szükséges definiálni, hogy mi is tartozik bele. Mi is pontosan a kibertér? A definíciójához Magyarország Nemzeti Kiberbiztonsági Stratégiájának megfogalmazását hívom segítségül: „A kibertér globálisan összekapcsolt, decentralizált, egyre növekvő elektronikus információs rendszerek, valamint ezen rendszereken keresztül adatok és információk formájában megjelenő társadalmi és gazdasági folyamatok együttesét jelenti. Magyarország kibertere a globális kibertér elektronikus információs rendszereinek azon része, amelyek Magyarországon találhatóak, valamint a globális kibertér elektronikus rendszerein keresztül adatok és információk formájában megjelenő társadalmi és gazdasági folyamatok közül azok, amelyek Magyarországon történnek, vagy Magyarországra irányulnak, illetve amelyekben Magyarország érintett."15

A kibertér definiálása után meg kell határozni, a kiberbiztonság fogalmát. Ennek definiálásához Kovács László professzor úr könyvét hívom segítségül: „A Nemzetközi Távközlési Egyesület (International Telecommunication Unit, ITU) által adott meghatározást hívjuk segítségül, amely alapján a kiberbiztonság az eszközök, politikák, biztonsági koncepciók, biztonsági garanciák, biztonsági technológiák, irányelvek, kockázatkezelési módszerek, tevékenységek, képzések, valamint a legjobb gyakorlatok összessége, amelyek arra irányulnak, hogy megvédjék a számítógépes környezetet, az ezt használó szervezetek és felhasználók eszközeit, rendszereit. Ezt a meghatározást alkalmazva levonhatjuk azt a következtetést, hogy a kiberbiztonság a jelenlegi és az elörejelezhető biztonsági kihívásokat kezeli, és biztosítja azt az állapotot, amelyben a szervezet működőképes, a felhasználó az eszközeit zavartalanul és biztonságosan tudja használni, hozzáfér az adataihoz és az információkhoz, valamint a szervezet különböző folyamatai az eredeti működési szándéknak megfelelő módon működnek."16

A fenti folyamatok és határok figyelembevételével, az alábbi biztonsági koncepciót dolgoztam ki mind az applikáció, mind annak adatai védelme érdekében.

Első és legfontosabb kérdés a regisztráció, illetve az applikációba belépés védelmének megtervezése és ezek felett a kontroll megtartása. Ennek több kritériuma van. Első és legfontosabb, hogy a regisztráció lehetőségét kizárólag az adott alakulat informatikai állománya végezhesse és engedélyezhesse. Így az ő eszközrendszerükön keresztül lehet kizárólag lehetővé tenni az applikáció használatát, ami azt eredményezi, hogy csak az MH személyi állományának van lehetősége az alkalmazást igénybe venni. Ezeken túl, nélkülözhetetlennek tartom, hogy az alkalmazás használata kétlépcsős azonosítás után történhessen meg (a belépés időtartama, ami becsléseim alapján 5-10 másodperc, még nem károsítja jelentősen a felhasználói élményt, és nem megy a használhatóság rovására).

1. lépcső: Biometrikus azonosítás (ujjlenyomat- vagy arcfelismerés), 2. lépcső személyi kód használata (összetett kód használata: 8 karakter, betủ és szám).

\footnotetext{
1139/2013. (III. 21.) Korm. határozat Magyarország Nemzeti Kiberbiztonsági Stratégiájáról 3. pont.

16 Kovács László: Kiberbiztonság és -stratégia. Budapest, Dialóg Campus Kiadó. 2018. 17.
} 
Kameratitkosítási szoftver: ez a személyi igazolójegy megreformálásának egyelőre szigorúan elméleti koncepciójához kapcsolódik. ${ }^{17}$ Az egészségügyi adatok kiolvasása a katona személyi igazolójegye QR-kódjából történhetne, viszont a jogosulatlan kiolvasások és adatszerzések megakadályozása érdekében, a QR-kóddal ellátott személyi igazolójegybe titkosítással tartom szükségesnek felvinni az egészségügyi adatokat. Ennek következtében az applikáció kamerakiolvasási funkciójába be kell építeni a kód dekódolási képességét.

A fejezet összefoglalásaként kijelenthető, hogy a civil applikációhasználati trendek, a népszerű funkcióknak megvan a helye akár egy katonai szervezet egészségügyi szolgálatánál. A koncepcióm kidolgozásánál egy komplex, összetett az élet számos területén hasznosítható okostelefonos alkalmazás került megtervezésre. A katonaállomány a beépített funkciók használatával mérhető időt tudna megtakarítani akár például az előjegyzési rendszer funkcióit használva, akár az otthoni gondoskodás chat funkcióját igénybe véve, de említhetjük a patika keresési funkciót is. Az egészségtudatos életmód és mindazok a lehetőségek, amelyek ezt körülveszik, napjainkra bizony trendé vált, az állományról való gondoskodás jegyében, valós elérhető, kézzelfogható sikereket várok esetleges bevezetésével, amennyiben ez a funkció is központi irányítás és tervezés alapján kerül müködtetésre.

\section{Az MH EÜ applikáció potenciális telemedicinális kapcsolódása}

Ebben a fejezetben célul tűztem ki, hogy megvizsgálom, az általam kifejlesztett applikáció mely funkciói illeszkedhetnek a telemedicinális ellátás koncepciójába. Mielőtt még ezt megteszem, szükségesnek tartom a telemedicina jelenségét definiálni. A telemedicina egyik legtalálóbb definíciója alapján olyan strukturált egészségügyi szolgáltatásként lehet jellemezni, ahol az ellátásban részesülő és az ellátott személy közvetlenül nem találkozik, a kapcsolat valamilyen távoli adatátviteli rendszeren keresztül jön létre.18 Ezt a lényegre törő definíciót talán azzal lehetne kiegészíteni, hogy felsoroljuk a kapcsolat lehetséges fajtáit:: ${ }^{19}$ a) Távkonzílium/szupervízió: ahol a diagnózis kialakításába, a kezelés menetébe kommunikációs eszközökön keresztül távoli orvos/szakszemélyzet is be van vonva. b) Távdiagnosztika: amikor a diagnózis alapját adó vizsgálat végzője és a diagnózis felállítója (a lelet készítője) térben elválik egymástól, de interaktív kapcsolatban vannak. c) Távfelügyelet/telemonitoring: amikor az egészségügyi szakszemélyzet jelenlétét a betegnél levő/őt figyelő jelfogók (detektorok) és jeltovábbítók pótolják. d) Távmanipuláció: amikor a vizsgálatot vagy beavatkozást végző személy távérzékelőkre támaszkodva távolról vezérli (végzi) az interakciót igénylő vizsgálatot (például endoszkópia) vagy beavatkozást (például videóvezérlés mellett robottal vagy távvezérlésre alkalmas eszközzel végzett távmanipuláció).

\footnotetext{
Matusz (2018) i. m. 377.

18 Fejes Zsolt: Új lehetőség a védelem-egészségügyi ellátásban: Telemedicina. Hadmérnök, 11. (2016), 1. $233-239$.

19 Telemedicina. Egészségtudományi fogalomtár. Elérhető: https://fogalomtar.aeek.hu/index.php/Telemedicina (A letöltés dátuma: 2019. 05. 26.)
} 
A felsorolás tartalmi elemeinek és az applikáció képességeinek vizsgálata után, összefoglalásként megállapítom, hogy a kifejlesztett egészségügyi applikációkoncepcióm több funkciója is megfelel a fent támasztott kritériumoknak. Az Otthoni gondoskodás funkció kimeríti a távkonzílium és a távdiagnosztika definícióját, ugyanis az egészségügyi szakállomány írásban, azaz chat- vagy hangalapon bevonódhat a kezelés menetébe, illetve a diagnózis kialakításába. Távfelügyelet/telemonitoring funkció is beletartozik ebbe a pontba, amennyiben az adott egészségi központ által kiadott 24 órás vérnyomásmérő rendelkezik telemedicinális adatküldő képességgel.

Az Egészségtudatos Életmód Program magában hordozhatja a sportolás során begyüjtött egészségügyi adatok kiértékelésének lehetőségét. Ennek a funkciónak az igénybevételével az orvosnak és az edzőnek a sportolás alatti egészségügyi adatokat, valamint azok értékeinek esetleges negatív változása esetén adva van a lehetőség akár az azonnali beavatkozásra.

\section{5. Összefoglalás - következtetések}

Összefoglalásként kijelenthető, hogy a civil szférában az applikációk területén már működő megoldások átültethetők a Magyar Honvédség csapategészségügyi rendszerének fejlesztése, valamint az állomány egészségügyi ellátásának fokozása céljából.

Azonosítottam, megneveztem és meghatároztam azokat a funkciókat, amelyek a csapategészségügyi ellátást megfelelő módon kiegészíteni, illetve fejleszteni képesek.

Prevenció és diagnosztika terén is használható a kiolvasási képesség, amely az okostelefon kameráját használja, a naptár funkció támogatja az ellátást igénylők hatékonyabb elosztását, ezzel együtt több figyelem fordulhat a betegre. Azok a naptári egészségügyi ellátási igény bejegyzések, amelyek nem igényelnek orvost, könnyebben tervezhetővé alakítják az egészségügyi ellátást, és ezzel egyidejüleg tehermentesítik az orvost is. Az adatbázis használata, a megfelelő adatvédelmi és biztonsági szabályok betartásával az ellátandó katonát teszik a fókuszba, egy speciális egészségügyi veszélyhelyzet esetén mérhetően emelve az ellátás színvonalát, de ez prevenciós nézőpontból megközelítve is megállja a helyét. Az otthoni gondoskodás funkciója megadja azt a pluszt az állománynak, hogy egészségügyi kérdés esetén sincs magára hagyva és megkapva a kérdéseire a választ, nem veszik el a civil ellátás útvesztőjében. Továbbá egyes meghatározott és szabályozott esetekben, amikor minden kétséget kizáróan megnyugtató választ kap a kérdéseire, a sürgősségi ellátás igénybevételének kihagyásával tehermentesítheti is a sürgősségi betegellátó osztályokat. Az Egészségtudatos Életmód Program bevezetése és elérhetősége, valamint annak igénybevétele esetén hatékonyan növelheti az állomány hadrafoghatóságát, kevés befektetéssel hozzájuttathatjuk az állományt a saját egészségének védelméhez.

A jelenlegi honvédségi ellátórendszer alkalmas az általam kifejlesztett applikáció integrálására, ugyanis az applikációban lévő funkciókban rejlő előnyök kiaknázásához kizárólag elöljárói szabályozási szándék szükséges. Ezt kiegészítve megjegyzem, hogy 
a szabályzók pontos, müködést és müködtetést támogató megfogalmazásához további kutatásokat javaslok.

Kiberbiztonság terén, az alkalmazás funkcióinak véglegesítése során mindenféleképpen együttmüködést javaslok a további fejlesztési és véglegesítési feladatok során a híradó-informatikai szakemberekkel. Az applikáció müködtetésének kiberbiztonsági szabályozására további kutatást javaslok.

Zárásként kijelenthető, hogy az applikáció bemutatott funkciói akár önállóan is „életképesek", azaz egy-egy részük integrálása is már járulékos előnyöket hozna a honvédségi egészségügyi ellátás terén. A kifejlesztett alkalmazás további hozadéka, hogy a potenciális felhasználók az applikáció igénybevételével több kontrollt érezhetnének az egészségük felett, ami mellett nem elhanyagolható tény, hogy egy komplett „ökoszisztéma” részeként ellenőrzötten érnék ezt el. Ennek következtében a telemedicina betöltene egy újabb funkciót is, egy aktív hídként tudna funkcionálni az EÜ-szolgálat és az állomány között, amivel hozzájárulhat az ellátási egyenlőtlenségek esetleges csökkentéséhez. ${ }^{20}$

\section{Felhasznált irodalom}

Bán Attila: Telemedicina és földrajz: egy innovatív egészségügyi ellátási forma és a földrajzi egyenlőtlenségek. Földrajzi Közlemények, 139. (2015), 4. 318-327.

Detschew, Stefan: Impact of ICT in the developing countries on the economic growth. Norderstedt, GRIN, 2007.

Fejes Zsolt: Új lehetőség a védelem-egészségügyi ellátásban: Telemedicina. Hadmérnök, 11. (2016), 1. 233-239.

Haig Zsolt: Az információs társadalom információbiztonsága. Bolyai Szemle, 17. (2008), 4. 167-180.

Az infokommunikációs technológiák és szolgáltatások helyzete Magyarországon, 2016. Központi Statisztikai Hivatal. Elérhető: www.ksh.hu/docs/hun/xftp/idoszaki/ ikt/ikt16.pdf (A letöltés dátuma: 2019. 04. 25.)

Kovács László: Kiberbiztonság és -stratégia. Budapest, Dialóg Campus, 2018.

Matusz Márk: A személyi igazolójegy („dögcédula”) fejlesztési lehetőségei a telemedicina vonatkozásában. Hadmérnök, 13. (2018), 4. 370-380.

Mobil Internet Statistics and Facts 2019. Internet Stats and Facts for 2019. Elérhető: https://hostingfacts.com/internet-facts-stats/ (A letöltés dátuma: 2019. 04. 25.)

\section{Jogi forrás}

1139/2013. (III. 21.) Korm. határozat Magyarország Nemzeti Kiberbiztonsági Stratégiájáról

20 Bán Attila: Telemedicina és földrajz: egy innovatív egészségügyi ellátási forma és a földrajzi egyenlőtlenségek. Földrajzi Közlemények, 139. (2015), 4. 318-327. 324. 


\section{Internetes források}

Doctoron Demand alkalmazás. Elérhető: https://itunes.apple.com/us/app/doctor-on-demand/id591981144? mt=8 (A letöltés dátuma: 2019. 04. 25.)

http://easy-marketing.eu (A letöltés dátuma: 2019. 04. 25.)

MediCall. Elérhető: https://medicall.cc (A letöltés dátuma: 2019. 04. 25.)

Medical Point+. Elérhető: https://itunes.apple.com/hu/app/medical-point/ id643000486?l=hu\&mt=8 (A letöltés dátuma: 2019. 04. 25.)

Medscape. Elérhető: www.medscape.com (A letöltés dátuma: 2019. 04. 25.)

Patikus. Elérhető: https://itunes.apple.com/hu/app/patikus/id579890723?l=hu\&mt=8 (A letöltés dátuma: 2019. 04. 25.)

Telemedicina. Egészségtudományi fogalomtár. Elérhető: https://fogalomtar.aeek.hu/ index.php/Telemedicina (A letöltés dátuma: 2019. 05. 26.)

WebDoki. Elérhetö: www.webdoki.hu/logon/?redirect=\%2F\#login (A letöltés dátuma: 2019. 04. 25.)

What is Army Knowledge Online? Elérhető: www.onlinemilitaryeducation.org/faq/ what-is-army-knowledge-online/ (A letöltés dátuma: 2019. 04. 25.)

Withings Health Mate. Elérhető: www.withings.com/nl/en/health-mate (A letöltés dátuma: 2019. 04. 25.) 